\title{
A randomised, double blind, multicentre trial of octreotide in moderate to severe acute pancreatitis
}

\author{
W Uhl, M W Büchler, P Malfertheiner, H G Beger, G Adler, W Gaus, and the German \\ Pancreatitis Study Group
}

Department of Visceral and

Transplantation Surgery, University of Bern, Bern,

Switzerland W Uhl

M W Büchler

Department of Internal Medicine, University of Magdeburg,

Magdeburg, Germany

$P$ Malfertheiner

Department of General Surgery and Internal Medicine, University of Ulm, UIm, Germany H G Beger

G Adler

Department of Biometry and Medical Documentation, University of Ulm, Ulm, Germany W Gaus

Correspondence to: Professor M W Büchler, Department of Visceral and Transplantation Surgery, University Hospital of Bern, Inselspital, CH-3010 Bern, Switzerland.

Accepted for publication 25 January 1999

\begin{abstract}
Background-The pharmacological inhibition of exocrine pancreatic secretion with the somatostatin analogue octreotide has been advocated as a specific treatment of acute pancreatitis.

Aim-To investigate the efficacy of octreotide in acute pancreatitis in a randomised, placebo controlled trial.

Methods-302 patients from 32 hospitals, fulfilling the criteria for moderate to severe acute pancreatitis within 96 hours of the onset of symptoms, were randomly assigned to one of three treatment groups: group $P(n=103)$ received placebo, while groups $\mathrm{O} 1(\mathrm{n}=98)$ and $\mathrm{O} 2(\mathrm{n}=101)$ received 100 and $200 \mu \mathrm{g}$ of octreotide, respectively, by subcutaneous injection three times daily for seven days. The primary outcome variable was a score composed of mortality and 15 typical complications of acute pancreatitis.
\end{abstract}

Results-The three groups were well matched with respect to pretreatment characteristics. An intent to treat analysis of all 302 patients revealed no significant differences among treatment groups with respect to mortality $(P: 16 \% ; O 1: 15 \% ; O 2$ : $12 \%$ ), the rate of newly developed complications, the duration of pain, surgical interventions, or the length of the hospital stay. A valid for efficacy analysis (251 patients) also revealed no significant differences.

Conclusions-This trial shows no benefit of octreotide in the treatment of acute pancreatitis.

(Gut 1999;45:97-104)

Keywords: acute pancreatitis; somatostatin; octreotide; randomised controlled multicentre trial

Acute pancreatitis is clinically classified into mild and severe forms. ${ }^{1}$ The majority of patients suffer from mild acute pancreatitis, a self limiting disease which responds well to conservative treatment. In up to $20 \%$ of patients with acute pancreatitis, however, the disease progresses to a severe form involving both pancreatic and extrapancreatic necrosis. While the morbidity and mortality of mild acute pancreatitis are low, patients with severe acute pancreatitis commonly develop systemic complications and have a mortality of $10-50 \%$, despite all currently available treatment strategies..$^{2-8}$

Although the initial steps in the pathogenesis of acute pancreatitis are not fully understood, the term "autodigestion", introduced by Chiari in 1896, summarises the prevailing concept that the acute inflammation is triggered by the activation of digestive enzymes. ${ }^{9} 10$ The earliest trial of somatostatin, a hormone which inhibits exocrine pancreatic secretion, as a rational therapeutic approach in human acute pancreatitis, yielded "an impressive clinical improvement". ${ }^{11}$ The findings of later, randomised trials of somatostatin in acute pancreatitis were controversial. ${ }^{12-17}$ However, a meta-analysis of all adequately designed studies concluded that somatostatin treatment reduced mortality from $14 \%$ to $6.2 \% .^{18}$ In contrast to experimental findings, ${ }^{19}$ clinical studies showed that basal exocrine secretion is essentially normal during the acute inflammatory phase of acute pancreatitis. ${ }^{20}{ }^{21}$ These results provoked interest in the synthetic somatostatin analogue octreotide as a potentially useful specific treatment for acute pancreatitis. In an open phase I/II study of patients with moderate and severe acute pancreatitis treated with three different doses of octreotide $(100,200$, or 500 $\mu \mathrm{g}$ three times daily), an apparent reduction in the rate of newly developed complications was found which was particularly pronounced in the $200 \mu \mathrm{g}$ group..$^{22}$ We were thus encouraged to evaluate the efficacy of this drug in a randomised, controlled, multicentre trial.

\section{Patients and methods}

This report was prepared in accordance with the Consolidated Standards of Reporting Trials (the "CONSORT statement"). ${ }^{23}$

STUDY DESIGN AND PROTOCOL

The study protocol was approved by the Ethics Committees of the Universities of Bern (Switzerland) and Ulm and Bremen (Germany). The two treatment groups received octreotide in different doses, $100 \mu \mathrm{g}$ three times daily (O1) and $200 \mu \mathrm{g}$ three times daily $(\mathrm{O} 2)$; the control group received placebo $(\mathrm{P})$. It was intended to enrol 100 patients in each group, as suggested by a power analysis (see below).

Patients with moderate or severe acute pancreatitis were the target group of the study; mild cases were excluded. To be enrolled,

Abbreviations used in this paper: ARDS, adult respiratory distress syndrome; CRF, case report form; CT, contrast enhanced computed tomography; ERCP, endoscopic retrograde cholangiopancreatography; ITT, intent to treat; $\mathrm{O}$, octreotide; $\mathrm{P}$, placebo; RCT, randomised controlled trial; SIRS, systemic inflammatory response syndrome; VFE, valid for efficacy. 


\section{Table 1 Inclusion criteria}

Necessary criteria

First symptoms of acute pancreatitis not more than 96 hours before enrolment

Serum amylase or lipase increased at least threefold during this period

Spontaneous upper abdominal pain during this period

Written informed consent to participate in the study ${ }^{\star}$

Supporting criteria (fulfilment of at least four required)

Local abdominal resistance

Subileus/ileus

Shock: pulse $\geqslant 100 / \mathrm{min}$ and systolic blood pressure $\leqslant 80 \mathrm{~mm} \mathrm{Hg}$ for more than 10 minutes

Arterial $\mathrm{Po}_{2}<60 \mathrm{~mm} \mathrm{Hg}$

Leucocyte count $>12 \mathrm{~g} / 1$

C-reactive protein $>120 \mathrm{mg} / 1$

Fasting blood glucose $>8.4 \mathrm{mmol} / 1 \dagger$

Hypocalcaemia $\leqslant 2.0 \mathrm{mmol} / 1$

Serum creatinine $>240 \mu \mathrm{mol} / 1$

Characteristic findings of moderate or severe acute pancreatitis on ultrasound or contrast enhanced CT

${ }^{\star}$ If the patient was not competent to give informed consent, the treating physician was allowed to decide in consultation with the patient's family.

†This criterion was not applied in patients with pre-existing diabetes mellitus.

Table 2 Exclusion criteria

Symptoms of acute pancreatitis present for more than

96 hours

Known chronic renal failure

Serum creatinine continuously $>480 \mu \mathrm{mol} / 1$

Patient with renal transplant

Patient undergoing chronic dialysis

Age under 18 years

Pregnancy

Psychosis (except alcoholic delirium)

Previous treatment with aprotinin, glucagon, calcitonin,

pirenzepine, atropine, native somatostatin

Second enrolment in the study (new enrolment on relapse not allowed)

Table 3 Optional treatments

Analgesics

Psychotropics ${ }^{\star}$

Antibiotics*

Treatment ${ }^{\star}$ directed at specific complications-for example, insulin, oxygen, mechanical ventilation, $\mathrm{H}_{2}$ antagonists/proton pump inhibitors

Dialysis or haemofiltration $\dagger$

Peritoneal lavaget

ERC/ERCP with/without papillotomy†

Interventional and surgical procedurest

*Type and dosages of the drugs were recorded in the case report forms (CRFs).

†The date and other specific information were recorded in the CRFs.

ERC, endoscopic retrograde cholangiography; ERCP, endoscopic retrograde cholangiopancreatography.

patients were required to fulfil four necessary criteria and four of 10 supporting criteria, as defined in a previous multicentre trial (table 1). ${ }^{8}$ The necessary and supporting criteria were waived in cases where the diagnosis of severe acute pancreatitis was confirmed by laparotomy within four days of the onset of symptoms. The exclusion criteria of the previous trial were also used in this trial (table 2$){ }^{8}$

BLINDING AND RANDOMISATION

Each of the participating centres received packages of vials containing either octreotide or placebo. A multiple of six packages $(6,12$, 18 , etc.) was sent to each centre. Each package contained equal numbers of vials for groups $\mathrm{P}$ $(n=2), O 1(n=2)$, and $\mathrm{O} 2(n=2)$ in a blinded fashion. The packages were used sequentially as the patients were enrolled in the study. There was thus a strict randomisation in three parallel groups in each hospital, and a strict double blind procedure was guaranteed. The unbroken codes of the individual packages were deposited with the chief investigator in each hospital. A provision was made that the code could be broken in case of severe adverse events after notification of both the principal investigator and trial coordinator.

\section{MEDICATION}

The study medication was stored at $2-8^{\circ} \mathrm{C}$. The first subcutaneous injection of the study medication was given immediately after enrolment of the patient. Further injections were given at eight hour intervals over the following seven days.

\section{BASAL TREATMENT}

The standardised basal treatment was according to generally accepted principles of supportive care in acute pancreatitis, ${ }^{8}$ including nothing by mouth diet, nasogastric tube (obligatory in severe acute pancreatitis, optional in moderate acute pancreatitis), central venous catheter, input/output monitoring, and adequate parenteral replacement of fluid and electrolytes. Lipid infusions were permitted, but parenteral hyperalimentation was not. Table 3 summarises further treatments used in some cases; these had to be recorded in the case report forms (CRF).

PRIMARY AND SECONDARY OUTCOME VARIABLES The efficacy of the treatment was assessed by a score composed of mortality and the occurrence of 15 typical complications (tables 4 and 5). Death was considered to be worse than all other complications together. Therefore, early deaths without complications were assessed

Table 4 Definitions of local, organ, and metabolic complications of severe acute pancreatitis

Local and organ complications
Shock

Sepsis

Pulmonary insufficiency

Renal insufficiency

Peritonitis

Haemorrhage

Abscess/infected pancreatic necrosis

Fluid collection

Ileus/subileus

Metabolic complications

Hypocalcaemia

Coagulopathy

Hyperglycaemia

Metabolic acidosis

Jaundice

Encephalopathy
Pulse $>100 / \mathrm{min}$ and systolic blood pressure $<80 \mathrm{~mm} \mathrm{Hg}$ for more than 10 minutes

Leucoctyes $>12 \mathrm{~g} / 1$ or $<4 \mathrm{~g} / 1$; platelets $<100 \mathrm{~g} / 1$; body temperature $>38.5^{\circ} \mathrm{C}$; positive blood culture; metabolic acidosis

(base excess greater than $-4 \mathrm{mmol} / \mathrm{l})$ ( 4 of 5 criteria required)

Arterial $\mathrm{PO}_{2}<8 \mathrm{kPa}(60 \mathrm{~mm} \mathrm{Hg})$ (despite 4 litres $\mathrm{O}_{2} / \mathrm{min}$ via nasal tube) or need for mechanical ventilation

Increase in serum creatinine to more than twice the normal value

Intraoperative finding of suppurative intra-abdominal infection

Gastrointestinal and/or intra-abdominal bleeding requiring $\geqslant 4$ units

Pus collection or infected fluid shown by ultrasound or CT guided fine needle aspiration and microbiological culture, or by (re)laparotomy

Fluid collection with an extent of $5 \times 5 \mathrm{~cm}$ or more on sonography or CT

Clinical or radiological signs of intestinal paralysis or obstruction

Calcium $\leqslant 2.0 \mathrm{mmol} /$

Prothrombin time $<70 \%$ and/or partial thromboplastin time $>45$ seconds

Blood glucose level $>8.4 \mathrm{mmol} / 1$

Base excess greater than $-4.0 \mathrm{mmol} /$

Total serum bilirubin $>20 \mu \mathrm{mol} / 1$

Neuropsychiatric symptoms, abnormal electroencephalogram (except alcoholic delirium) 
Table 5 Complication score as primary outcome variable

\begin{tabular}{llll}
\hline $\begin{array}{l}\text { Organ } \\
\text { complication }\end{array}$ & Points & $\begin{array}{l}\text { Metabolic } \\
\text { complication }\end{array}$ & Points \\
\hline Shock & 4 & Hypocalcaemia & 2 \\
Sepsis & 4 & Coagulopathy & 2 \\
Pulmonary insufficiency & 3 & Hyperglycaemia & 2 \\
Renal insufficiency & 3 & Metabolic acidosis & 2 \\
Peritonitis & 3 & Jaundice & 1 \\
Haemorrhage & 3 & Encephalopathy & 1 \\
Abscess & 3 & & \\
Pseudocyst & 3 & & \\
Ileus/subileus & 1 & & \\
Death & 38 & & \\
\hline
\end{tabular}

For each complication occurring in a patient the corresponding points were added. The number of points assigned to a complication express the clinical relevance of the complication for acute pancreatitis. Death was assigned 38 points (equal to the sum of all scores +1 ), because it is worse than all other complications together. Primary outcome was the sum of points at admission minus the sum of points for complications acquired during treatment. Hence, positive values of the score indicate improvement, negative values deterioration.

Table 6 Secondary outcome variables and clinical and laboratory parameters monitored for safety reasons

Secondary outcome variables

Total duration of pain until the patient became pain free Apache II score

Clinical and laboratory parameters

Blood pressure, pulse, temperature

Leucocytes, haematocrit, haemoglobin, platelets

Partial thromboplastin time, prothrombin time

Calcium

Glucose

Total bilirubin

Creatinine

Aspartate aminotransferase

Lactate dehydrogenase

Amylase

Lipase

C-reactive protein

Arterial $\mathrm{Po}_{2}$, base excess

adequately. The chief investigator in each hospital was advised to look for these complications each day during the treatment phase (day 0 to day 7) and in the follow up period on days $8-11,12-14$, and $15-21$, and on the day of discharge. The severity of acute pancreatitis during the study period was graded according to a scoring system defined in a previous study on the basis of these complications. ${ }^{8}$ The clinical change in each patient was calculated as the score given on enrolment in the trial, minus the total score for newly developed complications during hospitalisation. A zero or negative calculated value thus indicates clinical deterioration, while a positive value indicates clinical improvement.

The duration of pain and the Apache II scores over the study period were used as secondary outcome variables. Other parameters were monitored for safety reasons (table 6) daily from day 0 to day 7 , and thereafter at the same intervals as those used to assess efficacy.

The preparation, randomisation, and delivery of the study medication, as well as the monitoring of the study centres by checking the information in the CRFs, were carried out by Novartis (formerly Sandoz), Nuremberg (Germany). The study headquarters was located in the Department of Visceral and Transplantation Surgery of the University of Bern (Switzerland) and was responsible for medical problems, data checking, and data entry. Checking of the data for plausibility, and all statistical analyses, were performed by the Department of Biometry and Medical Documentation of the University of Ulm (Germany), after the code was broken.

\section{POWER ANALYSIS AND STATISTICS}

In the multicentre study with the use of gabexate mesilate in moderate to severe acute pancreatitis, the percentage of patients with one or more newly developed complications in the placebo group was $63 \% .^{8}$ In the present octreotide study, conducted in patients with disease of the same degree of severity, we hypothesised that octreotide treatment would reduce the complication rate from $63 \%$ to $35 \%$. A power analysis indicated that 100 patients would have to be enrolled in each of the three groups to detect such a reduction at

Table 7 Characteristics of the 302 patients in the intent to treat analysis

\begin{tabular}{|c|c|c|c|c|}
\hline Characteristics & Total $(n=302)$ & Placebo $(n=103)$ & O1 $(n=98)$ & $O 2(n=101)$ \\
\hline $\operatorname{Sex}(M / F)$ & $198 / 104$ & $62 / 41$ & $70 / 28$ & $66 / 35$ \\
\hline \multicolumn{5}{|l|}{ Age } \\
\hline Mean & 50 & 53.5 & 49.4 & 49.9 \\
\hline Range & $18-93$ & $19-93$ & $18-88$ & $21-87$ \\
\hline \multicolumn{5}{|l|}{ Aetiology } \\
\hline Alcohol & $126(42 \%)$ & $42(41 \%)$ & $41(42 \%)$ & $43(43 \%)$ \\
\hline Gallstones & $111(37 \%)$ & $38(37 \%)$ & $35(36 \%)$ & $38(38 \%)$ \\
\hline Alcohol + gallstones & $4(1 \%)$ & 0 & $2(2 \%)$ & $2(2 \%)$ \\
\hline Alcohol + others & $2(0.7 \%)$ & 0 & $1(1 \%)$ & $1(1 \%)$ \\
\hline Others & $59(20 \%)$ & $23(22 \%)$ & $19(19 \%)$ & $17(17 \%)$ \\
\hline Duration of pain (hours) ${ }^{\star}$ & $44(0-145)$ & $46(2-103)$ & $44(7-145)$ & $44(0-105)$ \\
\hline \multicolumn{5}{|l|}{ Severity of disease $†$} \\
\hline Ranson score & $3(0-9)$ & $3(1-8)$ & $3(0-8)$ & $3(0-9)$ \\
\hline Apache II score & $8(0-37)$ & $7(0-28)$ & $7(0-22)$ & $9(0-37)$ \\
\hline Complication score & $6(1-30)$ & $6(1-20)$ & $6(1-27)$ & $7(1-30)$ \\
\hline C-reactive protein & $148(0-777)$ & $150(0-438)$ & $141(2-777)$ & $146(1-510)$ \\
\hline \multicolumn{5}{|l|}{ CT findings $\ddagger$} \\
\hline Normal pancreas & $1(0.3 \%)$ & $1(1 \%)$ & 0 & 0 \\
\hline Oedema & $22(7 \%)$ & $10(10 \%)$ & $3(3 \%)$ & $9(9 \%)$ \\
\hline Oedema + exudate & $133(44 \%)$ & $48(47 \%)$ & $49(50 \%)$ & $36(36 \%)$ \\
\hline Necrosis $<30 \%$ & $70(23 \%)$ & $25(24 \%)$ & $17(17 \%)$ & $28(28 \%)$ \\
\hline Necrosis < $50 \%$ & $26(9 \%)$ & $4(4 \%)$ & $13(13 \%)$ & $9(9 \%)$ \\
\hline Necrosis $>50 \%$ & $12(4 \%)$ & $2(2 \%)$ & $5(5 \%)$ & $5(5 \%)$ \\
\hline Not performed & $38(13 \%)$ & $13(13 \%)$ & $11(11 \%)$ & $14(14 \%)$ \\
\hline Total & $302(100 \%)$ & $103(100 \%)$ & $98(100 \%)$ & $101(100 \%)$ \\
\hline
\end{tabular}

$\star$ Until enrolment; median values (range).

†Median values (range)

‡CT findings within 96 hours after onset of symptoms. 
Table 8 Characteristics of the 251 patients in the valid for efficacy analysis

\begin{tabular}{|c|c|c|c|c|}
\hline Characteristics & Total $(n=251)$ & Placebo $(n=90)$ & $O 1(n=78)$ & $O 2(n=83)$ \\
\hline $\operatorname{Sex}(M / F)$ & $169 / 82$ & $54 / 36$ & $58 / 20$ & $57 / 26$ \\
\hline \multicolumn{5}{|l|}{ Age } \\
\hline Mean & 50.6 & 54.3 & 48.5 & 48.7 \\
\hline Range & $18-93$ & $19-93$ & $18-84$ & $21-80$ \\
\hline \multicolumn{5}{|l|}{ Aetiology } \\
\hline Alcohol & $103(41 \%)$ & $33(37 \%)$ & $33(42 \%)$ & $37(45 \%)$ \\
\hline Gallstones & $96(38 \%)$ & $37(41 \%)$ & $29(37 \%)$ & $30(36 \%)$ \\
\hline Alcohol + gallstones & $2(0.8 \%)$ & 0 & 0 & $2(2 \%)$ \\
\hline Alcohol + others & $2(0.8 \%)$ & 0 & $1(1 \%)$ & $1(1 \%)$ \\
\hline Others & $48(19 \%)$ & $20(22 \%)$ & $15(19 \%)$ & $13(16 \%)$ \\
\hline Duration of pain (hours) ${ }^{\star}$ & $44(4-96)$ & $46(5-96)$ & $44(7-96)$ & $44(4-96)$ \\
\hline \multicolumn{5}{|l|}{ Severity of diseaset } \\
\hline Ranson score & $3(0-9)$ & $4(1-8)$ & $3(1-8)$ & $3(0-9)$ \\
\hline Apache II score & $7(0-37)$ & $7(0-28)$ & $7(0-22)$ & $9(0-37)$ \\
\hline Complication score & $6(1-27)$ & $6(1-20)$ & $6(1-27)$ & $6(1-27)$ \\
\hline C-reactive protein & $145(0-777)$ & $154(0-438)$ & $134(2-777)$ & $146(1-510)$ \\
\hline \multicolumn{5}{|l|}{ CT findings $\ddagger$} \\
\hline Normal pancreas & $1(0.4 \%)$ & $1(1 \%)$ & 0 & 0 \\
\hline Oedema & $19(8 \%)$ & $9(10 \%)$ & $2(3 \%)$ & $8(10 \%)$ \\
\hline Oedema + exudate & $115(46 \%)$ & $44(49 \%)$ & $42(54 \%)$ & $29(35 \%)$ \\
\hline Necrosis $<30 \%$ & $60(24 \%)$ & $22(24 \%)$ & $15(19 \%)$ & $23(28 \%)$ \\
\hline Necrosis $<50 \%$ & $19(8 \%)$ & $2(2 \%)$ & $10(13 \%)$ & $7(8 \%)$ \\
\hline Necrosis $>50 \%$ & $9(4 \%)$ & $2(2 \%)$ & $3(4 \%)$ & $4(5 \%)$ \\
\hline Not performed & $28(11 \%)$ & $10(11 \%)$ & $6(8 \%)$ & $12(14 \%)$ \\
\hline Total & $251(100 \%)$ & $90(100 \%)$ & $78(100 \%)$ & $83(100 \%)$ \\
\hline
\end{tabular}

^Until enrolment; median values (range).

†Median values (range).

‡CT findings within 96 hours of onset of symptoms.

the one sided $5 \%$ significance level with a power of $98.8 \%$. If the power is reduced to $80 \%$ a decrease in the complication rate from $63 \%$ to $45 \%$ can be detected under the same conditions.

Two orthogonal tests were applied to the primary and secondary outcome variables: the two octreotide groups, taken together, were tested against placebo (O1, $\mathrm{O} 2$ versus $\mathrm{P}$ ), and high dose octreotide was tested against low dose octreotide (O2 versus $\mathrm{O} 1)$. A $\chi^{2}$ or Fisher's exact test was applied for qualitative variables, and a Wilcoxon U or Kruskal-Wallis $\mathrm{H}$ test for quantitative variables.

The study was designed for one single outcome variable. However, the restriction to one outcome variable is only relevant if the study delivers a significant result. If several outcome variables are tested, but none of these tests is significant, this gives even more

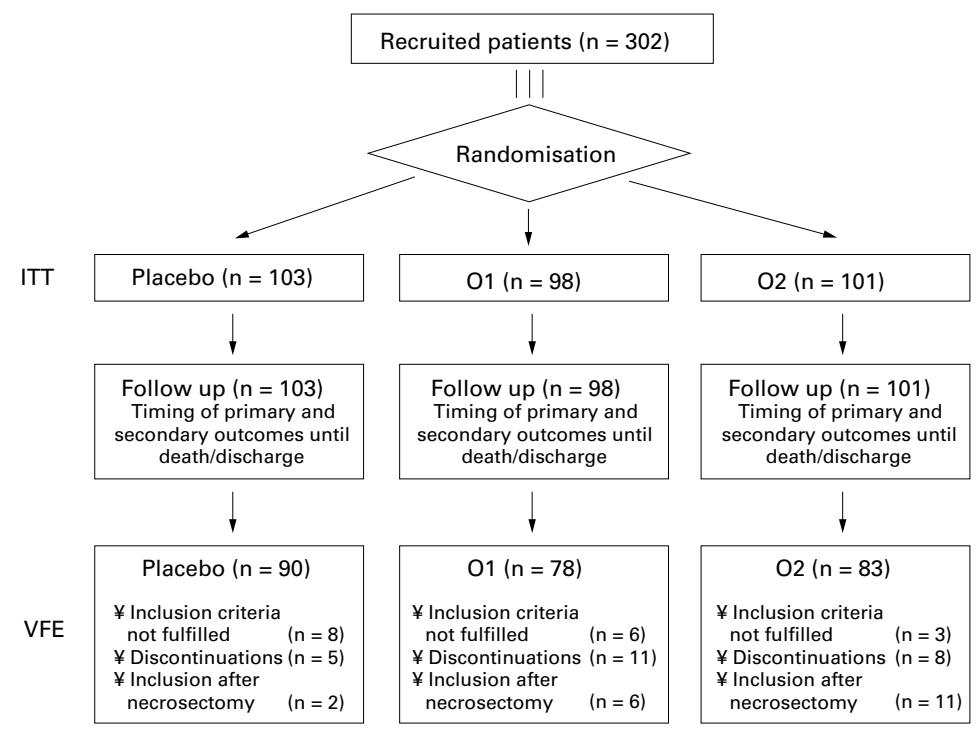

Figure 1 Flow chart of the allocation of patients to the study groups. ITT, intent to treat analysis; VFE, valid for efficacy analysis. Some patients were excluded for more than one reason. evidence that octreotide is not helpful in moderate to severe acute pancreatitis than one test on the primary outcome variable. In the case of non-significance the problem is not to control type 1 error, but to minimise type 2 error. The latter is true if no significance is achieved despite testing several outcome variables.

\section{Results}

PATIENT CHARACTERISTICS

Thirty one centres in Germany and one in Switzerland participated in this trial; 302 patients with moderate to severe acute pancreatitis were enrolled from November 1993 to March 1996. The mean age was 50 years (range 18-93); there were 198 men and 104 women (table 7). The aetiology of acute pancreatitis was alcohol abuse in 126 patients (42\%), gallstones in 111 (37\%), alcohol abuse and gallstones in four, alcohol and other causes in two, and other aetiologies in 59 (20\%). The median time elapsing from the onset of symptoms to entry into the study was 44 hours (range 0-145), and the patients fulfilled a median of five supporting criteria (range 3-10) on enrolment. The median Ranson, Apache II, and complication scores were 3 (range 0-9), 8 (range 0-37), and 6 (range 1-30) points, respectively. Contrast enhanced computed tomography (CT) was performed within 96 hours in $264(87 \%)$ of the 302 patients; pancreatic oedema with exudate, and varying extents of pancreatic and peripancreatic necrosis, were found in $133(44 \%)$ and 108 (36\%) patients, respectively.

The intent to treat (ITT) analysis included all 302 patients enrolled in the study. A total of 103 patients were treated with placebo $(\mathrm{P}), 98$ with octreotide $100 \mu \mathrm{g}$ three times daily (O1), and 101 with octreotide $200 \mu \mathrm{g}$ three times daily (O2). Table 7 gives the patient characteristics in the three treatment groups. Fifty one patients were excluded from the valid for efficacy (VFE) analysis for various reasons: 
Table 9 Primary and secondary outcome variables in the intent to treat analysis

\begin{tabular}{|c|c|c|c|c|}
\hline \multirow[b]{2}{*}{ Outcome variables } & \multirow[b]{2}{*}{$\begin{array}{l}\text { Total } \\
(n=302)\end{array}$} & \multicolumn{3}{|c|}{ Treatment groups } \\
\hline & & $\begin{array}{l}\text { Placebo } \\
(n=103)\end{array}$ & $\begin{array}{l}O 1 \\
(n=98)\end{array}$ & $\begin{array}{l}O 2 \\
(n=101)\end{array}$ \\
\hline Death & $43(14 \%)$ & $16(16 \%)$ & $15(15 \%)$ & $12(12 \%)$ \\
\hline Death $\leqslant 14$ days & 17 & 3 & 8 & 6 \\
\hline Death $>14 / \leqslant 30$ days & 9 & 3 & 3 & 3 \\
\hline Death $>30$ days & 17 & 10 & 4 & 3 \\
\hline $\begin{array}{l}\text { Patients with newly developed } \\
\text { complications }\end{array}$ & $220(73 \%)$ & $73(71 \%)$ & $74(76 \%)$ & $73(72 \%)$ \\
\hline Duration of pain $(\text { days })^{\star}$ & $6(0-209)$ & $6(0-209)$ & $6(0-105)$ & $7(1-156)$ \\
\hline Hospital stay (days) ${ }^{\star}$ & $21(0-210)$ & $21(2-210)$ & $21(0-112)$ & $22(2-163)$ \\
\hline
\end{tabular}

*Median values (range).

Table 10 Complications at inclusion of the patients and newly developed complications in the intent to treat analysis

\begin{tabular}{|c|c|c|c|c|}
\hline & \multirow{2}{*}{$\begin{array}{l}\text { Number of } \\
\text { patients with } \\
\text { complications at } \\
\text { inclusion } \\
(n=302)\end{array}$} & \multicolumn{3}{|c|}{$\begin{array}{l}\text { Number of patients with newly } \\
\text { developed complications }\end{array}$} \\
\hline & & $\begin{array}{l}\text { Placebo } \\
(n=103)\end{array}$ & $\begin{array}{l}O 1 \\
(n=98)\end{array}$ & $\begin{array}{l}\mathrm{O} 2 \\
(n=101)\end{array}$ \\
\hline \multicolumn{5}{|l|}{ Local and organ complications } \\
\hline Shock & 42 & 8 & 2 & 4 \\
\hline Sepsis & 14 & 4 & 4 & 5 \\
\hline Pulmonary failure & 98 & 20 & 13 & 17 \\
\hline Renal insufficiency & 25 & 5 & 7 & 5 \\
\hline Peritonitis & 13 & 2 & 1 & 7 \\
\hline Haemorrhage & 4 & 7 & 3 & 4 \\
\hline Abscess/infected pancreatic necrosis & 6 & 8 & 8 & 7 \\
\hline Fluid collection & 144 & 7 & 3 & 5 \\
\hline Ileus/subileus & 281 & 2 & 1 & 0 \\
\hline \multicolumn{5}{|l|}{ Metabolic complications } \\
\hline Hypocalcaemia & 108 & 32 & 31 & 26 \\
\hline Coagulopathy & 58 & 34 & 32 & 26 \\
\hline Hyperglycaemia & 191 & 14 & 15 & 18 \\
\hline Metabolic acidosis & 55 & 11 & 11 & 10 \\
\hline Jaundice & 167 & 15 & 14 & 19 \\
\hline Encephalopathy & 20 & 3 & 2 & 9 \\
\hline Death & 43 & 16 & 15 & 12 \\
\hline
\end{tabular}

Table 11 Primary and secondary outcome variables in the valid for efficacy analysis

\begin{tabular}{|c|c|c|c|c|}
\hline \multirow[b]{2}{*}{ Outcome variables } & \multirow[b]{2}{*}{$\begin{array}{l}\text { Total } \\
(n=251)\end{array}$} & \multicolumn{3}{|c|}{ Treatment groups } \\
\hline & & $\begin{array}{c}\text { Placebo } \\
(n=90)\end{array}$ & $\begin{array}{l}O 1 \\
(n=78)\end{array}$ & $\begin{array}{l}\mathrm{O} 2 \\
(n=83)\end{array}$ \\
\hline Death & $27(11 \%)$ & $13(14 \%)$ & $7(9 \%)$ & $7(8 \%)$ \\
\hline Death $\leqslant 14$ days & 4 & 1 & 2 & 1 \\
\hline Death $>14 / \leqslant 30$ days & 8 & 3 & 2 & 3 \\
\hline Death $>30$ days & 15 & 9 & 3 & 3 \\
\hline $\begin{array}{l}\text { Patients with newly developed } \\
\text { complications }\end{array}$ & $180(73 \%)$ & $61(68 \%)$ & $59(76 \%)$ & $60(72 \%)$ \\
\hline Duration of pain (days) ${ }^{\star}$ & $6(0-209)$ & $6(0-209)$ & $6(0-105)$ & $7(1-89)$ \\
\hline Hospital stay (days)^ & $21(5-210)$ & $22(7-210)$ & $21(5-105)$ & $20(7-163)$ \\
\hline
\end{tabular}

${ }^{\star}$ Median values (range). the frequency of necrosectomy at enrolment in the study $(p=0.023)$; however, even though this $\mathrm{p}$ value rose above the $5 \%$ significance level after adjustment for multiple testing with the Bonferroni-Holm correction, all patients with initial laparotomy and necrosectomy were excluded from the VFE analysis. Additionally, the influence of the centres on mortality was estimated with a logistic regression calculation. Neither the centres nor the treatment groups were significantly different in mortality according to either the ITT $(p=0.22$ and $p=0.85$, respectively) or VFE (both $\mathrm{p}=0.54$ ) analyses.

PRIMARY OUTCOME VARIABLES

In the ITT analysis, $14 \%(43 / 302)$ of the patients died, with a mortality of $16 \%$ (16/ 103), $15 \%$ (15/98), and $12 \%(12 / 101)$, in group $\mathrm{P}, \mathrm{O} 1$, and $\mathrm{O} 2$, respectively $(\mathrm{p}=0.71)$. The three groups also did not differ in early and late mortality (table 9). Nearly three quarters of the patients developed new complications in the course of the study ( $\mathrm{P}: \mathrm{n}=73,71 \%$, $\mathrm{O} 1: \mathrm{n}=74,76 \% ; \mathrm{O} 2: \mathrm{n}=73,72 \%)$; there was no significant difference among the three groups in the overall morbidity or in the frequency of each of the 15 specified complications (table 10). The median difference between the complication scores at inclusion and over the course of treatment (newly developed complications only) was 3 in the placebo group and 3 in the two octreotide groups combined $(p=0.12)$. The comparison of $\mathrm{O} 2$ with $\mathrm{O} 1$ revealed a median difference of complication scores of 4 in the high dose octreotide group, as opposed to 3 in the low dose octreotide group $(\mathrm{p}=0.059$; fig 2$)$. The VFE analysis yielded a mortality of $11 \%(27 / 251)$, distributed as $14 \%$ $(13 / 90)$ in group $\mathrm{P}, 9 \%(7 / 78)$ in $\mathrm{O} 1$, and $8 \%$ $(7 / 83)$ in $\mathrm{O} 2(\mathrm{p}=0.37)$. The other figures were similar to those found in the ITT analysis (table 11).

SECONDARY OUTCOME VARIABLES

The median duration of pain was six days in both $\mathrm{P}$ and $\mathrm{O} 1$, and seven days in $\mathrm{O} 2$, according to either the ITT analysis or the VFE analysis (tables 9 and 11). There were no differences in the Apache II score (fig 3) or in the laboratory parameters listed in table 6 .

Surgical intervention for necrosectomy was necessary in 46 patients during the course of the study, $19(18 \%)$ in $\mathrm{P}, 13(13 \%)$ in $\mathrm{O} 1$, and $14(14 \%)$ in O2. Other pancreatitis related operations (for example, relaparotomy for abscess, symptomatic postacute pseudocysts, etc., and cholecystectomy) were performed in 34 patients $(33 \%)$ in $\mathrm{P}, 34(35 \%)$ in $\mathrm{O} 1$, and 42 $(42 \%)$ in $\mathrm{O} 2$. The rates of surgical intervention were similar in the VFE patient population.

The median length of hospital stay was 21 days (range 0-210) in both the ITT and the VFE analyses and did not differ significantly among treatment groups (tables 9 and 11).

\section{Discussion}

The idea that the pharmacological inhibition of exocrine pancreatic secretion might serve as a specific treatment for acute pancreatitis has been a subject of controversy for more than 


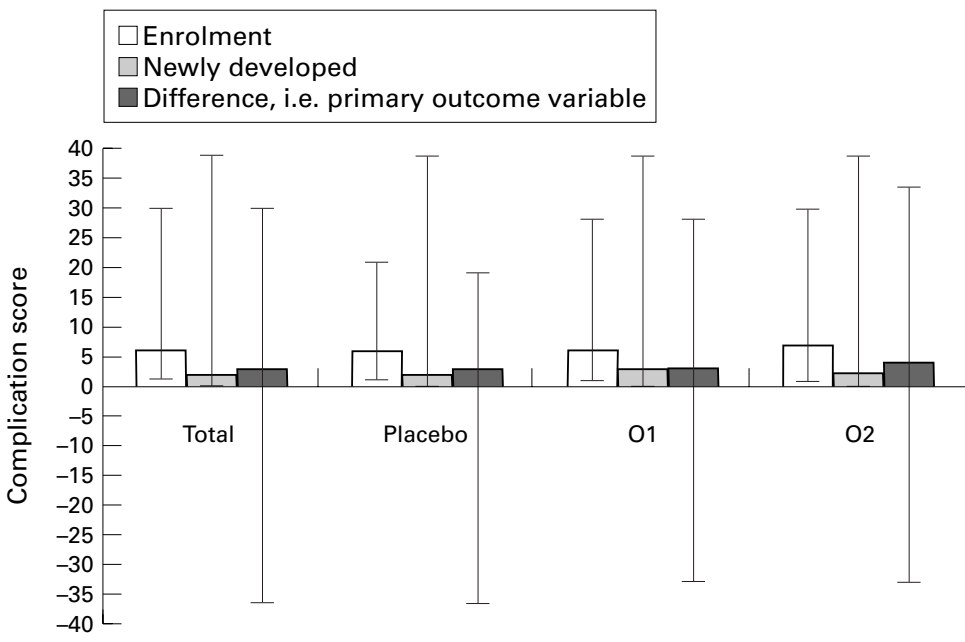

Figure 2 Scores for complications on enrolment, newly developed complications, and their difference in the intent to treat patient group. Results expressed as medians and ranges. The difference in complication scores (enrolment minus new complications) was computed for each patient. The median of the individual differences was then calculated.

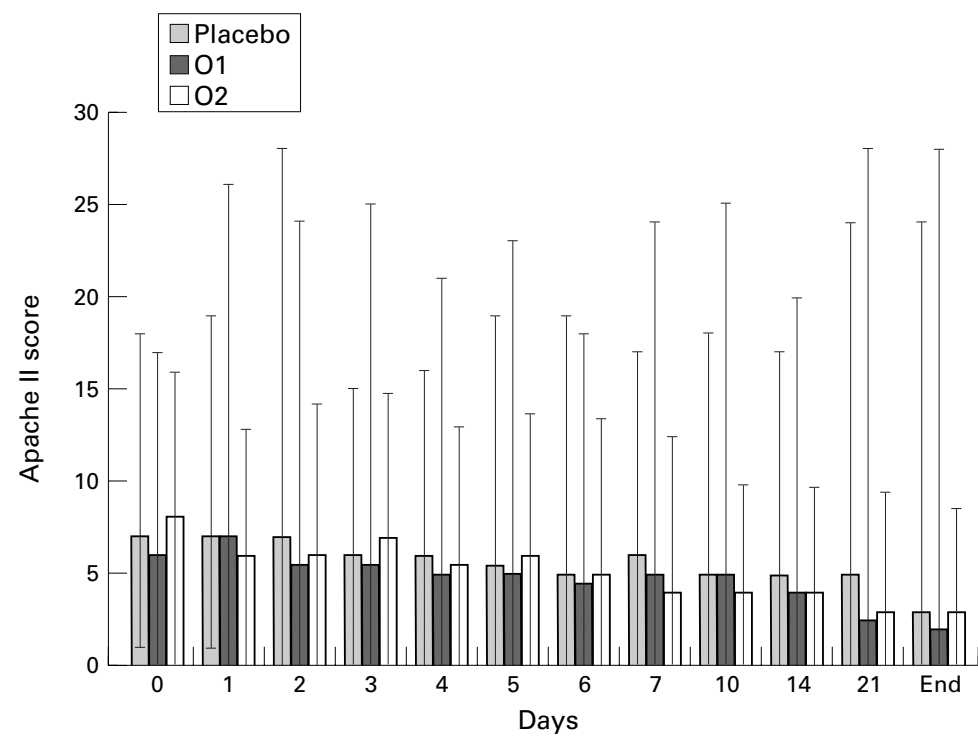

Figure 3 Course of the Apache II score in the intent to treat patient group. Results are expressed as medians and ranges.

three decades. Activated pancreatic enzymes seem to be involved in the generation and progression of this "autodigestive" acute inflammatory disease, and it was therefore hypothesised that the administration of somatostatin or its analogue octreotide might help prevent progression of the disease and its complications. Nonetheless, the present randomised, controlled, multicentre study, whose size and design give it the power to detect a major clinical benefit if present, found no evidence for any positive effect of octreotide treatment on the course and outcome of patients with moderate to severe acute pancreatitis.

The morbidity and mortality of severe acute pancreatitis are still distressingly high. ${ }^{2-5}$ Its natural course has two phases. The first phase (during the first two weeks after onset) is characterised by a systemic inflammatory response syndrome (SIRS) due to the liberation of vasoactive and toxic mediators by the necrotising process. ${ }^{24}{ }^{25}$ In the second phase (during the third week and beyond), septic complications occur as a result of infection of pancreatic necrosis. ${ }^{26}$

Although the initiating pathophysiological processes are not known, the disease is thought to result from destruction of the pancreas and peripancreatic fatty tissue by digestive enzymes which are produced in the acinar cells and activated intracellularly or extracellularly. ${ }^{9} 10$ Two treatment options might be of value to limit the "autodigestive" local damage and to interfere with SIRS in the early phase of acute pancreatitis: inhibition of the activated enzymes with protease inhibitors; or inhibition of exocrine secretion to "put the gland to rest" and prevent the further release and activation of digestive enzymes. Protease inhibitors (such as aprotinin and gabexate mesilate), hormones (such as calcitonin and glucagon), and atropine have all been clinically tested as possible specific treatments for acute pancreatitis, so far without success. ${ }^{6-8}$

Somatostatin and its analogue octreotide have been tested in several experimental models of acute pancreatitis, with contradictory results, sometimes negative, ${ }^{27-31}$ and sometimes positive. $^{32-37}$ The first clinical study of somatostatin treatment, published in 1980, revealed "an impressive improvement" in all 14 patients treated with a continuous intravenous infusion of somatostatin. ${ }^{11}$ This encouraging result provided the motivation for further trials, none of which showed a significant benefit on the prognosis of patients with acute pancreatitis. ${ }^{12-17}$ In 1991, Carballo and colleagues ${ }^{18}$ published a meta-analysis of six randomised clinical trials involving somatostatin. The individual trials had not revealed any statistically significant benefit; in the meta-analysis, however, the 207 patients in the somatostatin group had a significantly lower mortality than the 207 patients in the placebo group $(6.2 \%$ versus $14 \%, \mathrm{p}<0.01)$. A possible explanation for the apparent lack of effect in the individual clinical studies was suggested by the finding that, in various animal models of acute pancreatitis, the basal and stimulated pancreatic exocrine secretion are reduced or even nearly abolished. ${ }^{19}$ Yet this has been found not to be the case in human acute pancreatitis, where the initial interdigestive exocrine pancreatic secretion remains in the normal range or is even increased. ${ }^{20}{ }^{21}$

Octreotide, a long acting octapeptide analogue of the native hormone somatostatin, became clinically available in $1982 .^{38}$ It has proved to be a powerful inhibitor of basal and stimulated exocrine pancreatic secretion in healthy volunteers, and, unlike somatostatin, can be given subcutaneously. ${ }^{39}$ The results of a phase I/II study with three different octreotide dosages suggested a possible benefit in acute pancreatitis. ${ }^{22}$ The patients receiving $200 \mu \mathrm{g}$ of octreotide three times daily had fewer complications than those receiving $100 \mu \mathrm{g}$ three times daily, or than historical controls.

While our trial was being conducted, other clinical studies of somatostatin or octreotide treatment in acute pancreatitis were published, with conflicting results (table 12). ${ }^{40-46}$ These studies, however, are open to criticism: they either were not randomised, controlled 
Table 12 Prospective clinical studies using somatostatin or its analogue octreotide in human acute pancreatitis

\begin{tabular}{|c|c|c|c|c|c|c|c|}
\hline \multirow[b]{2}{*}{ Reference } & \multirow[b]{2}{*}{ Study design } & \multirow[b]{2}{*}{ Drug/dosage } & \multirow{2}{*}{$\begin{array}{l}\text { Number of } \\
\text { patients }\end{array}$} & \multicolumn{2}{|l|}{ Complications } & \multicolumn{2}{|l|}{ Mortality } \\
\hline & & & & Controls & Treatment & Controls & Treatment \\
\hline Gjorup and colleagues ${ }^{40}$ & $\begin{array}{l}\text { RCT, } \\
\text { multicentre }\end{array}$ & $\begin{array}{l}\text { Somatostatin } \\
250 \mu \mathrm{g} / \mathrm{h} \text { for } 3 \text { days }\end{array}$ & 63 & $30 \%(9 / 30)$ & $42 \%(14 / 33)$ & $3 \%(1 / 30)$ & $3 \%(1 / 33)$ \\
\hline Luengo and colleagues $^{41}$ & $\mathrm{RCT}$ & $\begin{array}{l}\text { Somatostatin } \\
250 \mu \mathrm{g} / \mathrm{h} \text { for } 48 \mathrm{~h}\end{array}$ & 100 & NA & NA & $2 \%(1 / 50)$ & $2 \%(1 / 50)$ \\
\hline Beechey-Newman ${ }^{42}$ & Open & $\begin{array}{l}\text { Octreotide } \\
0.5 \mu \mathrm{g} / \mathrm{kg} / \mathrm{h} \text { for } 10 \text { days }\end{array}$ & 19 & NA & NA & $0 \%$ & $0 \%$ \\
\hline $\mathrm{O}^{\prime} \mathrm{Hair}$ and colleagues ${ }^{43}$ & RCT & $\begin{array}{l}\text { Octreotide } 100 \mu \mathrm{g} \text { t.i.d. } \\
\text { s.c. until discharge }\end{array}$ & 180 & $10 \%(9 / 90)$ & $3 \%(3 / 90)$ & $0 \%$ & $1 \%(1 / 90)$ \\
\hline Paran and colleagues ${ }^{44}$ & Open & $\begin{array}{l}\text { Octreotide } 100 \mu \mathrm{g} \text { t.i.d. } \\
\text { s.c. for } 14 \text { days }\end{array}$ & 38 & $\begin{array}{l}74 \%(14 / 19) \\
63 \%(12 / 19)\end{array}$ & $\begin{array}{l}26 \%(5 / 19)^{\dagger} \\
37 \%(7 / 19)^{\ddagger}\end{array}$ & $31 \%(6 / 19)$ & $10.5 \%(2 / 19)$ \\
\hline Fiedler and colleagues ${ }^{45}$ & Case controlled & $\begin{array}{l}\text { Octreotide } 100 \mu \mathrm{g} \text { t.i.d. } \\
\text { i.v. for } 10 \text { days }\end{array}$ & 93 & $\begin{array}{l}87 \%(47 / 59) \\
40 \%(21 / 59)\end{array}$ & $\begin{array}{l}51 \%(26 / 39) \subseteq \\
18 \%(7 / 39)\end{array}$ & $61 \%(33 / 54)$ & $26 \%(10 / 39)^{\star}$ \\
\hline McKay and colleagues $^{46}$ & $\begin{array}{l}\text { RCT, } \\
\text { multicentre }\end{array}$ & $\begin{array}{l}\text { Octreotide } 40 \mu \mathrm{g} / \mathrm{h} \\
\text { i.v. for } 5 \text { days }\end{array}$ & 58 & $37 \%(11 / 30)$ & $53 \%(15 / 28)$ & $20 \%(6 / 30)$ & $18 \%(5 / 28)$ \\
\hline Present study & $\begin{array}{l}\text { RCT, } \\
\text { multicentre }\end{array}$ & $\begin{array}{l}\text { Octreotide } 100 \mu \text { t.i.d. } \\
\text { s.c. for } 7 \text { days } \\
\text { Octreotide } 200 \mu \text { t.i.d. } \\
\text { s.c. for } 7 \text { days }\end{array}$ & 302 & $\begin{array}{l}71 \%(73 / 103) \\
71 \%(73 / 103)\end{array}$ & $\begin{array}{l}76 \%(74 / 98) \\
72 \%(73 / 101)\end{array}$ & $\begin{array}{l}16 \%(16 / 103) \\
16 \%(16 / 103)\end{array}$ & $\begin{array}{l}15 \%(15 / 98) \\
12 \%(12 / 101)\end{array}$ \\
\hline
\end{tabular}

RCT, randomised controlled trial; NA, not assessed.

${ }^{\star} \mathrm{p}<0.05 ;$ † sepsis, $\mathrm{p}=0.004 ;$ \#ARDS, $\mathrm{p}=0.1 ;$ \shock, $\mathrm{p}<0.05 ; \uparrow \operatorname{ARDS}, \mathrm{p}<0.05$.

trials, ${ }^{42} 44$ included mainly patients with mild acute pancreatitis, ${ }^{40-43}$ or contained only a small number of patients. ${ }^{40-42} 44-46$ The present multicentre trial sought to overcome all these problems by including a sufficiently large number of patients with an adequate level of disease severity, and randomising them to either octreotide or placebo treatment within 96 hours of the onset of symptoms. This period was chosen so that the patients in the study would all be in the early phase of the disease. From early surgical interventions in severely ill patients, and from serial measurements of C-reactive protein, it has been shown that pancreatic necrosis develops early in the course of the disease (within 96 hours), regardless of the underlying aetiology. ${ }^{478}$ It therefore seemed reasonable to evaluate the possible benefit of octreotide within this early, "vulnerable" period. The severity of acute pancreatitis among the patients in our study can be seen from the median Ranson and Apache II scores (3 and 8, respectively), from the overall mortality rate $(14 \%)$, and from the fact that $80 \%$ of the patients had initial CT findings consistent with severe acute pancreatitis of Ranson grade C or worse ${ }^{49}$ However, octreotide was not found to be beneficial to our patients, either in the intent to treat $(n=302)$ or in the valid for efficacy $(n=251)$ analysis.

In other clinical circumstances, octreotide has been found beneficial if given prophylactically before invasive pancreatic procedures are performed, such as ERCP, ${ }^{50}$ elective pancreatic surgery, ${ }^{51-54}$ and pancreatic transplantation. ${ }^{55}$ However, for the great majority of patients with acute pancreatitis, prophylactic treatment is not possible; octreotide therapy may well come too late, because of the unavoidable interval between the onset of symptoms and hospitalisation. This problem is likely to impair the usefulness of any drug, not just octreotide, used to interfere with the early phase of acute pancreatitis.

In conclusion, octreotide treatment for acute pancreatitis cannot be recommended on the basis of our results. The early phase of severe acute pancreatitis with SIRS can be managed successfully today with maximal intensive care support, without any specific medication directed against the pathophysiological process of acute pancreatitis. In the late phase, however, septic complications frequently occur and are the most important risk factor for death. Preventing infection of pancreatic necrosis thus seems to be the most promising approach to the treatment of this disease at present. $^{26}$ 56-59

The German Pancreatitis Study Group: M W Büchler, W Uhl, $\mathrm{R}$ Vogel, and S Schmid, Department of Surgery, University Hospital of Bern; H G Beger and B Rau, Department of Surgery, University Hospital of Ulm; H P Bruch and G Kolbert, Department of Surgery, University of Lübeck; P G Lankisch and R Mahlke, Department of Internal Medicine, Städt. Krankenhaus Lüneburg; G Adler and B Glasbrenner, Department of Internal Medicine, University of Ulm; D Lorenz, Department of Surgery, University of Greifswald; $H$ Bünte and U Sulkowski, Department of Surgery, University of Münster; $H$ Goebel and M Rünzi, Department of Internal Medicine, University of Essen; W Kozuschek, Department of Surgery, Knappschaftskrankenhaus Langendreer Bochum; $\mathrm{H}$ Troidl and E Eypasch, Department of Surgery, University of Koln; I Klempa, Department of Surgery, Krankenhaus der Freien Hansestadt Bremen; G Allmendinger, Department of Internal Medicine, Klinik am Eichert Göppingen; S Liebe and M Löhr, Department of Internal Medicine, University of Rostock; J Witte, $M$ Wienbeck and $N$ Zügel, Departments of GastroenterDepartment of Surgery, University of Regensburg; A Hornung, Department of Surgery, Krankenhaus Bad Cannstatt; G Ramadori, Department of Gastroenterology and Endocrinology, University of Göttingen; E L Zurmeyer, Department of Surgery, Klinikum Ludwigshafen; W F Caspary, Department of Gastroenterology, University of Frankfurt; W Hartig, Department of Surgery, Städt. Klinikum St Georg Leipzig; R Bähr, Department of Surgery, Städt. Klinikum Karlsruhe; B Kremer, Department of Surgery, University of Kiel; P Czygan, Department of Internal Medicine, Lukaskrankenhaus Neuss; P Malfertheiner and U von Arnim, Department of Internal Medicine, University of Magdeburg; J Mössner, Department of Internal Medicine, University of Leipzig; D Kraus, Department of Surgery, Klinikum Nürnberg; D Häussinger and C Niederau, Department of Internal Medicine, University of Düsseldorf; T Sauerbruch, Department of Internal Medicine, University of Bonn; H Lippert and H U Schulz, Department of Surgery, Uni-
versity of Magdeburg; M Rothmund, Department of Surgery, versity of Magdeburg; M Rothmund, Department of Surgery,
University of Marburg; E Farthmann, Department of Surgery, University of Marburg; E Farthmann, Department of Surgery, University of Freiburg; W Schmiegel, Department of Internal Medicine, Knappschaftskrankenhaus Langendreer Bochum.
We are indebted to the patients, to the chief investigators and We are indebted to the patients, to the chief investigators and
physicians at the participating hospitals, and to Dr Ethan Taub for editorial assistance.

1 Bradley EL III. A clinically based classification system of acute pancreatitis. Arch Surg 1993;128:586-90.

2 Karimgani I, Porter KA, Langevin ER, et al. Prognostic factors in sterile pancreatic necrosis. Gastroenterology 1992; 103:1636-40.

3 Beger HG, Büchler M, Bittner R, et al. Necrosectomy and postoperative local lavage in necrotizing pancreatitis. $\mathrm{Br} \mathcal{F}$ 1988;75:207-21.

4 Sarr MH, Nagorney DM, Much P, et al. Acute necrotizing pancreatitis: management by planned, staged pancreatic 
necrosectomy/debridement and delayed primary wound closure over drains. Br 7 Surg 1991;78:576-81.

5 Ratner DW, Legermate DA, Lee MJ, et al. Surgical debridement of symptomatic pancreatic necrosis is beneficial irrespective of infection. Am 7 Surg 1992;163:105-10.

6 Steinberg WM, Schlesselmann SE. Treatment of acute pancreatitis: comparison of animal and human studies. Gastroenterology 1987;93:1420-7.

7 Leese $T$, Holliday $M$, Watkins $M$, et al. A multicentre controlled clinical trial of high-volume fresh frozen plasm therapy in prognostically severe acute pancreatitis. Ann $R$ Coll Surg Engl 1991;73:207-14.

8 Büchler M, Malfertheiner P, Uhl W, et al. Gabexate mesilate in human acute pancreatitis. Gastroenterology 1993;104 $1165-70$

9 Chiari H. Ueber die Selbstverdauung des menschlichen Pankreas. Z Heilk 1896;17:69-96.

10 Adler G, Kern HF, Scheele GA. Experimental models and concepts of acute pancreatitis. In: Go VLW, et al, eds. The concepts of acute pancreatitis. In: Go VLW, et al, eds. The

11 Limberg K, Kommerell, B. Treatment of acute pancreatitis with somatostatin. N Engl f Med 1980;79:284.

12 Usadel KH, Uberla KK, Leuschner U. Treatment of acute pancreatitis with somatostatin. results of the multicentre double-blind trial (APTS). Dig Dis Sci 1985;30:A992

13 Schöndube F, Klempa I, Baca I, et al. Nekrotisierende Pankreatitis-ein Beitrag zur stadiengerechten operativen Therapie. ACA 1987;19:354-5.

14 Zuniga J, Garcia L, Ortiz J, et al. Estudio de la efficacia del tratamiento con somatostatina en pancreatitis agudes grave. Proc de las XIV fornadas Hispano-Francesas De Gastroenterolog. Burgas: 10th Reunion de la Associationn Castelleno del Aparta Digestiva, October, 1987:39-40.

15 Sanchez D, Sanchez A, Zucdo JR, et al. Pancreatitis aguda. Estudio clinico y terrapeutico valoracion de la somatostatin. Ann Med Intern (Madrid) 1988;(suppl 3):A40.

16 Choi TK, Mok F, Zhan WH, et al. Somatostatin in the treatment of acute pancreatitis: a prospective randomised ment of acute pancreatitis: a prosp

17 D'Amico D, Favia C, Biasiato $\mathrm{R}$, et al. The use of somatostatin in acute pancreatitis: results of a multicentre somatostatin in acute pancreatitis: results
trial. Hepatogastroenterology 1990;37:92-8.

18 Carballo F, Dominguez-Munoz JE, Fernandez-Calvet L, et al. Is somatostatin useful in the treatment of acute pancreatitis? A meta-analysis. Digestion 1991;49:A12-13.

19 Niederau C, Niederau M, Lüthen R, et al. Pancreatic exocrine secretion in acute experimental pancreatitis. Gastroenterology 1990;99:1120-7.

20 Regan PT, Malagelada JR, Go VLW, et al. A prospective study of the antisecretory effects of cimetidine and glucagon in human acute pancreatitis. Mayo Clin Proc 1981;56:499-503.

21 Dominguez-Munoz JE, Pieramico O, Büchler M, et al. Exocrine pancreatic function in the early phase of human acute pancreatitis. Scand $\mathcal{F}$ Gastroenterol 1995;30:186-91.

22 Binder M, Uhl W, Friess H, et al. Octreotide in the treatment of acute pancreatitis: results of a unicenter prospective trial with three different octreotide dosages. Digestion 1994;55:20-3.

23 Begg C, Cho M, Eastwood S, et al. Improving the quality of reporting of randomized controlled trials: the CONSORT statement. ҰAMA 1996;276:637-9.

24 Beger HG, Bittner R, Büchler M, et al. Hemodynamic data pattern in patients with acute pancreatitis. Gastroenterology 1986;90:74-9.

25 Büchler M, Malfertheiner P, Schädlich $\mathrm{H}$, et al. Role of phospholipase A2 in human acute pancreatitis. Gastroenterology 1989;97:1521-6.

26 Beger HG, Bittner R, Block S, et al. Bacterial contamination of pancreatic necrosis. A prospective study. Gastroenterology 1986;91:433-8.

27 Degertekin H, Ertan A, Akdamar K, et al. Effects of somatostatin and a somatostatin agonist on diet-induced pancreatitis in mice. Peptides 1985;6:1245-7.

28 Schlarmann DE, Beinfeld MC, Andrus C, et al. Effects of somatostatin on acute canine experimental pancreatitis. Int SPancreatol $1987 ; 2: 247-55$

29 Murayama KM, Drew FB, Joehl RJ. Does somatostatin analogue prevent experimental acute pancreatitis? Arch Surg logue prevent exp

30 Metrakos P, Rosenberg L, Duguid WP, et al. Prophylactic sandostatin potentiates acute pancreatitis. Surg Forum 1990;41:160-1.

31 Zhu ZH, Holt S, El-Lbishi MS, et al. A somatostatin analoque is protective against retrograde bile salt-induced pancreatitis in the rat. Pancreas 1991;6:609-13.

32 Lankisch PG, Koop H, Winckler K, et al. Somatostatin therapy of acute pancreatitis. Gut 1977;18:713-16.

33 Schwedes U, Althoff PH, Klempa I, et al. Effect of somatostatin on bile-induced acute hemorrhagic pancreatitis in the dog. Horm Metab Res 1979;11:655-61.
34 Mann NS, Mauch MJ, Barnett R. Intraductal somatostatin protects against experimentally induced pancreatitis. Gastroenterology 1980;78:1217.

35 Baxter JN, Jenkins SA, Day DW, et al. Effects of somatostatin and a long-acting somatostatin analogue on the prevention and treatment of experimentally induced acute pancreatitis. Br F Surg 1985;72:382-5.

36 Baxter JN, Jenkins SA, Day DW, et al. Effects of a somatostatin analogue on hepatic and splenic reticuloendothelial function in rats. Br F Surg 1985;75:1005-8.

37 Augelli NV, Hussain SM, McKain MM, et al. Effect of SMS 201-995 (a long-acting somatostatin analogue) on bileinduced acute hemorrhagic pancreatitis in the dog. Arch Surg 1989;55:389-91.

38 Bauer W, Briner U, Doepfner WW, et al. SMS 201-995: a very potent and selective octapeptide analogue of somatostatin with prolonged action. Life Sci 1982;31:1133-40.

39 Kemmer TP, Malferteiner P, Büchler M, et al. Inhibition of human exocrine pancreatic secretion by the long-acting somatostatin analogue octreotide (SMS 201-995). Aliment Pharmacol Ther 1992;6:41-50.

40 Gjorup I, Roikjaer O, Andersen B, et al. A double-blinded multicenter trial of somatostatin in the treatment of acute pancreatitis. Surg Gynecol Obstet 1992;175:397-400.

41 Luengo L, Vicente V, Gris F, et al. Influence of somatostatin in the evolution of acute pancreatitis-a prospective randomized study. Int $\mathcal{F}$ Pancreatol 1994;15:139-44.

42 Beechey-Newmann N. Controlled trial of high-dose octreotide in treatment of acute pancreatitis. Dig Dis Sci 1993;38: 644-7.

43 O'Hair DP, Hoffmann RG, Schroeder H, et al. Octreotide in the treatment of acute pancreatitis: a prospective, randomized trial [abstract]. Gastroenterology 1993;104:A326.

44 Paran H, Neufeld D, Mayo A, et al. Preliminary report of a prospective randomized study of octreotide in the treatment of severe acute pancreatitis. F Am Coll Surg 1995;181: $121-4$.

45 Fiedler F, Jauernig G, Keim V, et al. Octreotide treatment in patients with necrotizing pancreatitis and pulmonary failure. Intensive Care Med 1996;22:909-15.

46 McKay C, Baxter J, Imrie C. A randomized, controlled trial of octreotide in the management of patients with acute pancreatitis. Int 7 Pancreatol 1997;21:13-19.

47 Isenmann R, Büchler M, Uhl W, et al. Pancreatic necrosis is an early finding in severe acute pancreatitis. Pancreas 1993; 8:358-61.

48 Uhl W, Isenmann R, Curti G, et al. Influence of the etiology on the course and outcome of acute pancreatitis. Pancreas 1996;13:335-43.

49 Ranson JHC, Balthazar E, Caccavale R, et al. Computed tomography and the prediction of pancreatic abscess in acute pancreatitis. Ann Surg 1985;201:656-65.

50 Bordas JM, Toledo V, Mondelo F, et al. Prevention of pancreatic reactions by bolus somatostatin administration in patients undergoing endoscopic retrograde cholangiopancreatography and endoscopic sphincterotomy. Hormone Res 1988:29:106-8.

51 Büchler M, Friess H, Klempa I, et al. The role of somatostatin analogue octreotide in the prevention of postoperative complications following pancreatic resection. The results of a multicenter controlled trial. Am f Surg 1992;163:125-30.

52 Pederzoli P, Bassi C, Falconi M, et al. Efficacy of octreotide in the prevention of complications of elective pancreatic surgery. Br F Surg 1994;81:265-9.

53 Friess H, Beger HG, Sulkowski U, et al. Randomized controlled multicentre study of the prevention of complications by octreotide in patients undergoing surgery for chronic pancreatitis. Br f Surg 1995;82:1270-3.

54 Montorsi M, Zago M, Mosca F, et al. Efficacy of octreotide in the prevention of pancreatic fistula after elective pancreatic resections: a prospective, controlled, randomized clinical trial. Surgery 1995;117:26-31.

55 Stratta RJ, Taylor RJ, Lowell JA, et al. Selective use of somatostatin in vascularized pancreas transplantation. Am f Surg 1993;166:598-605.

56 Büchler M, Malfertheiner P, Friess H, et al. Human pancreatic tissue concentration of bactericidal antibiotics. Gastroenterology 1992;103:1902-8.

57 Pederzoli P, Bassi C, Vesentini S, et al. A randomized multicenter clinical trial of antibiotic prophylaxis of septic complications in acute necrotizing pancreatitis with imipenem. Surg Gynecol Obstet 1993;176:480-3.

58 Luiten EJT, Hop WCJ, Lanje JF, et al. Controlled clinical trial of selective decontamination for the treatment of severe acute pancreatitis. Ann Surg 1995;222:57-65.

59 Sainio V, Kemppainen E, Puolakkainen P, et al. Early antibiotic treatment in acute necrotising pancreatitis. Lancet 1995;346:663-7. 